\section{Economic Profitability of Growing Lettuce and Tomato in Western Washington under High Tunnel and Open-field Production Systems}

\author{
Suzette P. Galinato ${ }^{1,3}$ and Carol A. Miles ${ }^{2}$
}

AdDITIONAL INDEX WORDs. net returns, production costs, Solanum lycopersicum, Lactuca sativa

Summary. Lettuce (Lactuca sativa) and tomato (Solanum lycopersicum) are popular fresh market vegetable crops. In western Washington, there is interest in growing them in high tunnel production systems because of the region's mild, coastal climate. The objectives of this study were to contrast the economic potential of growing lettuce and tomato under high tunnel and open-field production systems, and identify the main factors affecting profitability within each production system. Economic data for this study were collected by interviewing experienced lettuce and tomato growers in western Washington during focus group sessions. Costs of production varied by crop and production system, and findings indicated that it was five times more costly to grow lettuce and eight times more costly to grow tomato in a high tunnel than in the open field in western Washington. For lettuce, the labor cost per square foot of growing area was found to be 6 times greater in a high tunnel than in the open field; and for tomato, labor costs were 10 times greater in a high tunnel than in the open field. Total labor cost comprised more than $50 \%$ of the total production costs of lettuce and tomato in both the high tunnel and open-field systems. The percentage of total labor cost was similar in both the high tunnel and open-field production for lettuce, but was higher in high tunnel tomato production than in the open field. Tunnel-grown lettuce and tomato had three and four times greater marketable yield compared with field-grown, respectively. Given the base crop yield and average price, it was $43 \%$ more profitable to grow lettuce in the open field than in the high tunnel, while in contrast, high tunnel-grown tomato was three times more profitable than open-field tomato production.

$\mathrm{H}$ igh tunnels are used worldwide to protect crop quality under adverse weather conditions and to extend the production season of crops through climate enhancement (Lamont, 2009; Zhao and Carey, 2009). Temperature modification under high tunnels can lengthen the growing season from 1 to 4 weeks in the spring, and 2 to 8 weeks in the autumn (Wells and Loy, 1993). High tunnels are generally considered to be temporary structures covered with greenhouse-grade plastic, have no electrical system, and crops in them are planted directly into the soil (Wells and Loy, 1993). The range in engineering

This study is funded by the NIFA Specialty Crops Research Initiative, USDA SCRI-SREP Grant Award No. 2009-02484

We thank Debra Inglis and Thomas Marsh for their helpful comments on an early draft of this manuscript, and Chris Benedict for his technical support with this study.

${ }^{1}$ IMPACT Center, School of Economic Sciences, Washington State University, Pullman, WA 99164

${ }^{2}$ Department of Horticulture and Landscape Architecture, Washington State University, Mount Vernon NWREC, 16650 State Route 536, Mount Vernon, WA 98273

${ }^{3}$ Corresponding author. E-mail: sgalinato@wsu.edu. strength and durability of high tunnel technology generally corresponds to the range of purchase price (Giacomelli, 2009). The recent focus on locally grown food combined with low-cost tunnel technology has stimulated interest in crop-specific information relative to high tunnels among specialty crop growers (Reeve and Drost, 2012).

High-value crops including leafy greens, tomato, pepper (Capsicum annuиm), small fruit, tree fruit, and ornamentals are commonly produced in high tunnels in the United States (Carey et al., 2009). Lettuce (head, leaf, and romaine types combined) ranked first in the United States in total value of production of fresh market vegetables
(U.S. Census Bureau, 2012) and national consumption exceeded $23 \mathrm{lb}$ per capita each year on average between 1980 and 2010 [U.S. Department of Agriculture (USDA), 2012]. Lettuce production peaked in Washington in 1990 with 1700 acres, but by 1999 dropped to 800 acres, and has not been tracked thereafter (USDA, 2011). Washington farmers mostly lost market contracts to farmers in California who can supply large quantities of lettuce year-round (U.S. Census Bureau, 2012).

The optimal temperature for lettuce production is $65{ }^{\circ} \mathrm{F}$ (Maynard and Hochmuth, 1997), making this crop well suited for year-round production in regions with mild temperatures such as western Washington (Dufault et al., 2006). Lettuce generally benefits most from high tunnel production during fall, winter, and spring seasons, and is not normally grown in high tunnels during the summer because long daylength and elevated temperatures promote bolting, which reduces lettuce quality and marketability (Mishagi et al., 1992; Wien, 1997). In regions such as western Washington, heavy rainfall in the spring can constrain land preparation for crop establishment, and can negatively impact crop quality (Wallace et al., 2012).

In regions with a moderate climate such as the Pacific northwestern United States, production of warmseason crops such as tomato is limited (Miles et al., 2012; Rader and Karlsson, 2006; Waterer, 2003). In 2007, there were 300 acres of tomatoes produced by 409 farms in Washington, with a total estimated value of $\$ 1$ million to \$1.2 million (USDA, 2010; Washington State Commission on Pesticide Registration, 2010). Tomato production occurs on small acreages in essentially every county in Washington, and is predominantly for fresh market. While tomato is a minor crop in terms of overall production and value in

\begin{tabular}{llll}
\hline $\begin{array}{l}\text { Units } \\
\text { To convert U.S. to SI, } \\
\text { multiply by }\end{array}$ & U.S. unit & SI unit & $\begin{array}{l}\text { To convert SI to U.S., } \\
\text { multiply by }\end{array}$ \\
\hline 0.4047 & $\mathrm{acre}(\mathrm{s})$ & $\mathrm{ha}$ & $2.471 \mathrm{l}$ \\
0.3048 & $\mathrm{ft}$ & $\mathrm{m}$ & 3.2808 \\
0.0929 & $\mathrm{ft}^{2}$ & $\mathrm{~m}^{2}$ & 10.7639 \\
2.54 & inch $(\mathrm{es})$ & $\mathrm{cm}$ & 0.3937 \\
0.4536 & $\mathrm{lb}$ & $\mathrm{kg}$ & 2.2046 \\
1.1209 & $\mathrm{lb} / \mathrm{acre}$ & $\mathrm{kg} \cdot \mathrm{ha}^{-1}$ & 0.8922 \\
4.8824 & $\mathrm{lb} / \mathrm{ft}^{2}$ & $\mathrm{~kg} \cdot \mathrm{m}^{-2}$ & 0.2048 \\
$\left({ }^{\circ} \mathrm{F}-32\right) \div 1.8$ & ${ }^{\circ} \mathrm{F}$ & ${ }^{\circ} \mathrm{C}$ & $\left({ }^{\circ} \mathrm{C} \times 1.8\right)+32$ \\
& & &
\end{tabular}


Washington, it is considered an essential produce item at every farmers market, community supported agriculture farm, and other direct or local marketing outlet. Tomato benefits from high tunnel production in spring, summer, and fall months in western Washington. In a study by Miles et al. (2012), it was possible to plant tomato 1 to 2 months earlier in the spring in high tunnels than in the open field; during the summer months, plant growth was faster because of elevated temperatures and tomato was ready for harvest earlier; and in the fall, the crop was protected from rainfall and light frost, enabling harvest through October.

Although lettuce and tomato are both grown in high tunnels in western Washington, high tunnel production of both crops is currently low, and was estimated by the authors to be 50 acres for tomato and less than 20 acres for lettuce (Galinato et al., $2012 a, 2012 b$ ). The adoption rate for high tunnels is low in the region primarily due to a general lack of knowledge about the specific production practices for each crop, the high tunnel structures best suited to each crop, potential returns from high tunnels, and the capital investment needed to initiate and maintain high tunnel production (Miles et al., 2009). In addition, some experienced high tunnel growers in the region claimed that the following factors serve as barriers to more widespread adoption of high tunnels in northwest Washington: high cost of tunnel production in terms of capital investment, time, and effort; lack of experience with tunnel set up and management; lack of horticultural experience with crops requiring high labor input; low knowledge base to manage tunnel operation, maintenance, and repairs; and lack of understanding of the optimal planting dates and varieties for production (M. Finger, personal communication; D. Hedlin and K. Ottenson, personal communication; A. Schwartz, personal communication; T. Thornton, personal communication).

While high tunnels provide growers with the potential to increase production, quality, and sales, little is known about the economic profitability of using these structures. Some studies have looked at the economics of high tunnel crop production (Conner et al., 2010; Jett, 2011; Waldman et al., 2012; Waterer, 2003; Wien et al., 2010) but none except Rodriguez et al. (2012) have directly examined the profitability of crop production in a high tunnel system as compared with an open-field system. Single crop enterprise budgets have been developed for both field and high tunnel production of lettuce and tomato in western Washington (Galinato and Miles, 2012; Galinato et al., 2012a, 2012b, 2012c). The objectives of this study were to 1 ) compare the economic potential of growing lettuce and tomato in high tunnel and open-field production systems and 2) identify the main factors that affect the profitability of each crop within each production system.

\section{Materials and methods}

Four focus group meetings, each comprised of three to four growers, were convened in western Washington between Apr. and Nov. 2011 to develop crop enterprise budgets. Each focus group addressed one crop (lettuce or tomato) and one production system (open field or high tunnel). Focus group participants were selected based on their experience in growing lettuce or tomato in open field or high tunnel and their management practices. All growers who participated were experienced and knowledgeable in the crop and production system. Each focus group consisted of different growers, except for one grower who grew both lettuce and tomato in high tunnels, and participated in the high tunnel lettuce and tomato focus group meetings. All focus group participants grew several vegetable crops, and lettuce or tomato was one of the primary crops they each produced. Participants had 3 to 15 years of experience growing lettuce or tomato in the open-field or high tunnel system, and their farm area actually planted with tomato or lettuce ranged from less than 1 acre up to 6 acres. These growers were also representative of good and best management practices for the region. Participants sold their produce through direct marketing at a farmers market, food co-operative, and/or community supported agriculture venture. Table l summarizes the participants' farming background relevant for the study.

For each crop enterprise budget, a hypothetical farm situation was defined and the types of inputs were itemized based on the production system (i.e., high tunnel or open field) and vegetable crop selected (i.e., lettuce or tomato). The quantities of various inputs were based on the cultural and management practices of growers who participated in the focus group meetings. The focus groups for open-field production of lettuce and tomato defined a total production area equivalent to 1.5 and 1.25 acres as a baseline, respectively, where 1 acre was the growing area (rows and beds) and the remaining area was not used for direct crop production (alleyway, road, other utility areas). The growing season for field-grown lettuce was defined as April to October, and for field-grown tomato was February to September. Lettuce harvest was June to October, while tomato harvest was August to September.

For lettuce and tomato high tunnel production, the respective focus groups identified the high tunnel as $20 \times 96 \mathrm{ft}$ with end walls. Each grower had a different high tunnel model, and some had a three-season structure while others had a four-season structure. Since lettuce is well suited to cool spring temperatures, lettuce can be planted earlier in a four-season structure than in a three-season structure. Three-season structures cannot be erected in western Washington until April due to muddy field conditions. Further, it can be difficult to construct a three-season structure under other adverse weather conditions common during the early spring months in the region (heavy rainfall and wind). To reach consensus regarding costs and returns for high tunnel lettuce, growers participating in focus groups agreed to the following assumptions: 1) a three-season structure high tunnel was set up in mid-April and taken down in November, 2) the growing season (seed through harvest) was February to mid-October, and 3 ) the harvest season was late April to mid-October. The assumption for high tunnel-grown tomato was that the crop was set out in high tunnels when the minimum nightly temperature was $50^{\circ} \mathrm{F}$, which generally occurs by late April in the region. As three-season and four-season high tunnels are in place at this time of year, tomato was planted at the same time in both types of structures. The growing season (seed through harvest) for tomato was 1 Feb. to 1 Oct. and harvest season was June/July to 1 Oct.

The focus group participants established that the baseline marketable 


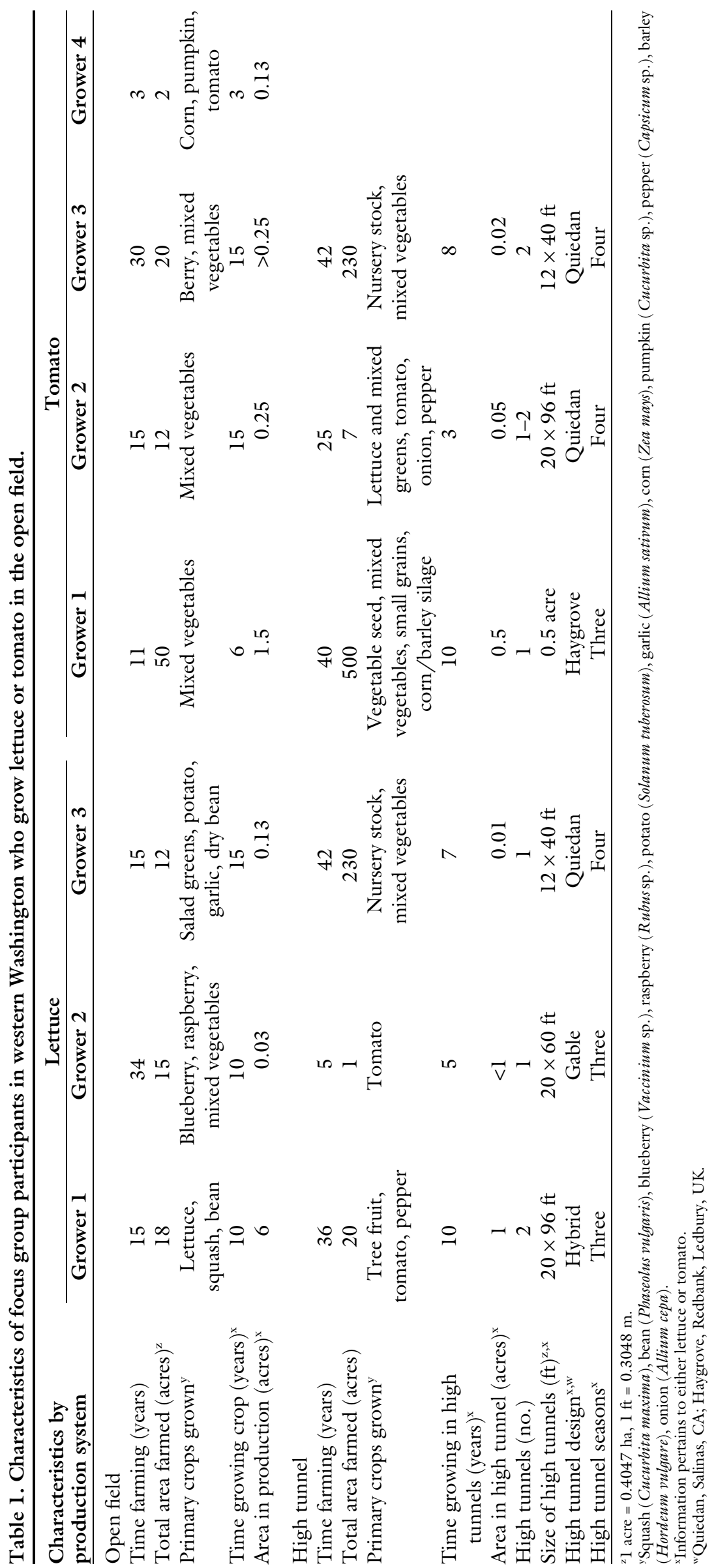

yield per square foot per harvest season was 0.36 head $/ \mathrm{ft}^{2}$ for field-grown lettuce and $0.56 \mathrm{lb} / \mathrm{ft}^{2}$ for tomato (Table 2). These baseline marketable yields were both within the range of previously reported values of 0.29 $0.67 \mathrm{head} / \mathrm{ft}^{2}$ and $0.43-1.94 \mathrm{lb} / \mathrm{ft}^{2}$, respectively (Antonelli et al., 2004; Jeavons, 2006; Veseys, n.d.; Wiswall, 2009). For high tunnel-grown lettuce and tomato, the baseline marketable yield per square foot established by focus group participants was 0.90 head $/ \mathrm{ft}^{2}$ and $2.25 \mathrm{lb} / \mathrm{ft}^{2}$, respectively. These high tunnel yields were much greater than the aforementioned field-grown yield range; specifically up to three times greater than the field-grown lettuce yield and up to five times greater than the fieldgrown tomato yield. The focus group results for tomato are similar to those reported in a western Washington study where tomato yield was eight times greater in the high tunnel than the open field (Miles et al., 2012). Table 2 shows other production specifications established by focus group participants for the two crops and the two production systems.

To account for variable production costs and returns among different farm operations (crop yield, input prices, commodity price, capital, labor, cultural practices and management skills, among others), baseline budget assumptions were established that served as a discussion guide for each focus group. Each focus group met for $4 \mathrm{~h}$ on $\mathrm{l} \mathrm{d}$ at a central location for all participating growers, and the participants discussed the budget assumptions. Main production categories were identified and estimates for the variable and fixed costs of production were provided by participating growers. Variable production costs were soil preparation, fertilizer and chemical application, planting, other labor, harvest and postharvest activities, maintenance and repairs of irrigation system, machinery and/or equipment, overhead, and interest on operating capital. The cost category "overhead" captured variable overhead costs as well as a factor for unforeseeable expenses. Fixed production costs were depreciation and interest on physical capital, interest and tax on land, farm insurance, and farm management. Because growers had different cost estimates for inputs used in production, each focus group achieved a consensus 
on the average cost for each production category. Specific crop cultural practices for each grower were also taken into account when discussing and determining the costs and returns of production. For example, participants in the open-field lettuce group were organic growers and participants in the open-field tomato group used plastic mulch. Production costs associated with different types of activities were then tabulated and reviewed by focus group participants and knowledgeable vegetable crop extension specialists in the region.
The values provided by focus group participants did not account for unforeseen production failures. Since crop loss should be anticipated periodically, sensitivity analyses were conducted on potential net returns from crop production (per square foot of total production area) given different crop yield and price scenarios. In particular, the net returns of crop production in a high tunnel or open-field production system were calculated, given a range of crop prices and three scenarios of crop yield: 1) base yield, 2 ) yield that was $20 \%$ less than base yield, and 3 ) yield that was $20 \%$ greater than base yield.

\section{Results}

COST PER UNIT OF TOTAL PRODUCTION AREA. A comparison of the production costs per square foot of total production area for each crop and production system are shown in Tables 3 and 4 . The total production costs of high tunnel lettuce and tomato were respectively five and eight times greater than those of open-field lettuce and tomato (Table 3). A breakdown of the production costs by field activity

Table 2. Baseline production values from focus group growers for lettuce and tomato in the open-field and high tunnel systems in western Washington in 2011.

\begin{tabular}{|c|c|c|c|c|}
\hline \multirow[b]{2}{*}{ Field specification } & \multicolumn{2}{|c|}{ Lettuce } & \multicolumn{2}{|c|}{ Tomato } \\
\hline & Open field & High tunnel $^{\mathrm{z}}$ & Open field & High tunnel $^{\mathrm{z}}$ \\
\hline Total production $\operatorname{area}^{\mathrm{y}, \mathrm{x}}$ & 1.5 acres & $1,920 \mathrm{ft}^{2}$ & 1.25 acres & $1,920 \mathrm{ft}^{2}$ \\
\hline Growing season & April to Oct. & February to mid-Oct. & February to Sept. & 1 Feb. to 1 Oct. \\
\hline Harvest season & June to Oct. & April to mid-Oct. & August to Sept. & June/July to 1 Oct. \\
\hline In-row spacing (inches) $)^{y}$ & 10 & 10 & 24 & 12 \\
\hline Marketable yield ${ }^{v}$ & 19,500 heads/acre & 1,725 heads/tunnel & $30,360 \mathrm{lb} /$ acre & $4,320 \mathrm{lb} /$ tunnel \\
\hline Early season $(\% \text { of total })^{\mathrm{u}}$ & NA & 30 & NA & 15 \\
\hline Midseason (\% of total) & 100 & 55 & 100 & 60 \\
\hline Late season $(\% \text { of total })^{\mathrm{u}}$ & NA & 15 & NA & 25 \\
\hline Marketable yield $/ \mathrm{ft}^{2 \mathrm{t}}$ & 0.36 head $/ \mathrm{ft}^{2}$ & 0.9 head $/ \mathrm{ft}^{2}$ & $0.56 \mathrm{lb} / \mathrm{ft}^{2}$ & $2.25 \mathrm{lb} / \mathrm{ft}^{2}$ \\
\hline
\end{tabular}

${ }^{2}$ High tunnel size was $20 \times 96 \mathrm{ft}(6.1 \times 29.3 \mathrm{~m})$. High tunnel was a three-season structure set up in mid-April and taken down in November.

$\mathrm{y} l$ acre $=0.4047 \mathrm{ha}, \mathrm{l \textrm {ft } ^ { 2 }}=0.0929 \mathrm{~m}^{2}, \mathrm{l}$ inch $=2.54 \mathrm{~cm}$

${ }^{x}$ Total production area included the growing area and area not devoted to direct production of the crop (road, walkpath, etc.)

${ }^{\mathrm{w}}$ Growing area was the total crop production area and excluded alleyways, processing station, and other utility areas.

${ }^{v} 1$ head $/$ acre $=2.4711$ heads $/$ ha, 1000 heads $/$ tunnel $=0.5208$ head $/ \mathrm{ft}^{2}=5.6062$ heads $/ \mathrm{m}^{2}, 1$ plant $/$ acre $=2.4711$ plants $/$ ha, 100 plants $/$ tunnel $=0.0521$ plants $/ \mathrm{ft}^{2}=$ $0.5605 \mathrm{plant} / \mathrm{m}^{2}, \mathrm{l} \mathrm{lb} /$ acre $=1.1209 \mathrm{~kg} \cdot \mathrm{ha}^{-1}, 1000 \mathrm{lb} /$ tunnel $=0.5208 \mathrm{lb} / \mathrm{ft}^{2}=2.5429 \mathrm{~kg} \cdot \mathrm{m}^{-2}$

"NA = not applicable.

${ }^{\mathrm{t}}$ Marketable yield per square foot of total production area; 1 head $/ \mathrm{ft}^{2}=10.7639$ heads $/ \mathrm{m}^{2}, 1 \mathrm{lb} / \mathrm{ft}^{2}=4.8824 \mathrm{~kg} \cdot \mathrm{m}^{-2}$

Table 3. Estimated annual production costs and net returns from focus group growers for lettuce and tomato in open-field and high tunnel production systems in western Washington in 2011.

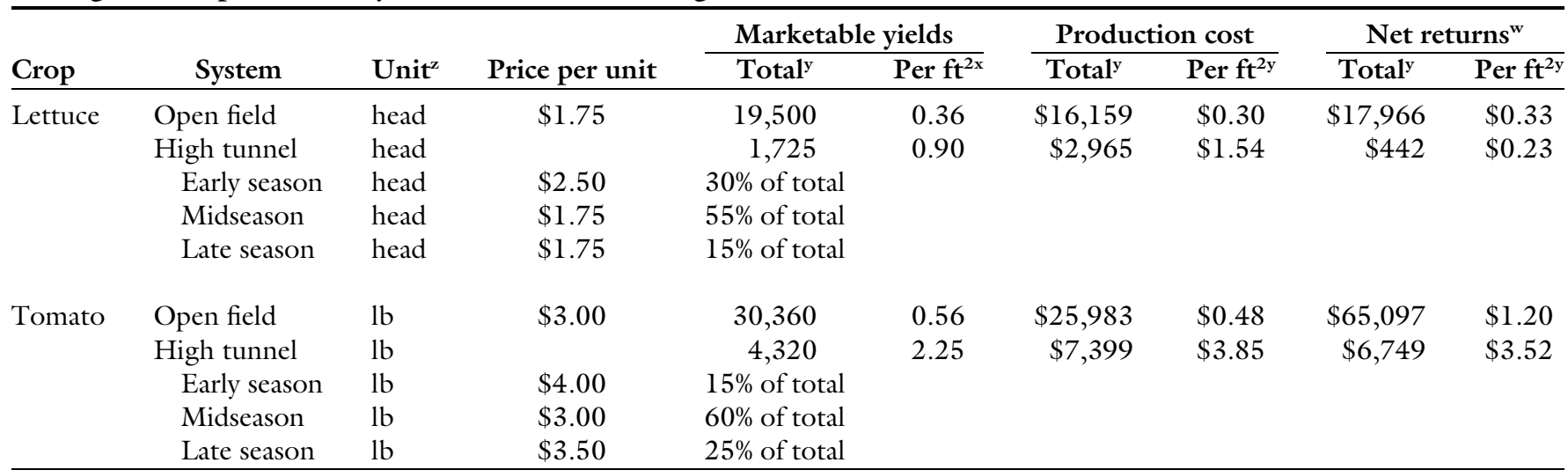

\footnotetext{
${ }^{\mathrm{z}} 1 \mathrm{lb}=0.4536 \mathrm{~kg}$.
}

${ }^{y}$ Numbers were expressed as total for the given total production area: 1.5 acres $(0.61$ ha $)$ for open-field lettuce; 1.25 acres $(0.506$ ha $)$ for open-field tomato; and one tunnel $=1920$ $\mathrm{ft}^{2}\left(178.4 \mathrm{~m}^{2}\right)$ for high tunnel lettuce and high tunnel tomato; l head $/ \mathrm{acre}=2.4711$ heads $/ \mathrm{ha}, 1000$ heads $/$ tunnel $=0.5208 \mathrm{head} / \mathrm{ft}^{2}=5.6062 \mathrm{heads} / \mathrm{m}^{2}, \mathrm{l} \mathrm{lb} / \mathrm{acre}=$ $1.1209 \mathrm{~kg} \cdot \mathrm{ha}^{-1}, 1000 \mathrm{lb} /$ tunnel $=0.5208 \mathrm{lb} / \mathrm{ft}^{2}=2.5429 \mathrm{~kg} \cdot \mathrm{m}^{-2}, \$ 1.00 / \mathrm{acre}=\$ 2.471 \mathrm{l} / \mathrm{ha}, \$ 1000 / \mathrm{tunnel}^{2}=\$ 0.5208 / \mathrm{ft}^{2}=\$ 5.6062 / \mathrm{m}^{2}, \$ 1.00 / \mathrm{ft}^{2}=\$ 10.7639 / \mathrm{m}^{2}$. ${ }^{x}$ Marketable yield per square foot of total production area; 1 head $/ \mathrm{ft}^{2}=10.7639$ heads $/ \mathrm{m}^{2}, 1 \mathrm{lb} / \mathrm{ft}^{2}=4.8824 \mathrm{~kg} \cdot \mathrm{m}^{-2}$

${ }^{w}$ Net returns $=$ (price per unit $\times$ marketable yield $)-$ production cost. For high tunnel lettuce and tomato, net returns were calculated by taking into account the different prices and

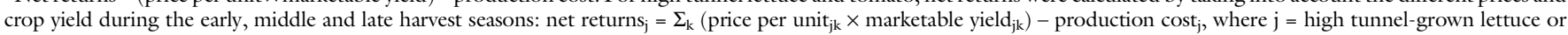
tomato, and $\mathrm{k}=$ early season, midseason, or late season. 
further showed the more costly operation of a high tunnel system per square foot (Table 4). The total labor cost for open-field production included field operations, harvest and postharvest activities, and was $\$ 0.14 / \mathrm{ft}^{2}$ for lettuce and $\$ 0.30 / \mathrm{ft}^{2}$ for tomato. In contrast, the total labor cost for high tunnel production included the additional cost of tunnel operation and maintenance, and was $\$ 0.89 / \mathrm{ft}^{2}$ for lettuce and $\$ 12.87 / \mathrm{ft}^{2}$ for tomato.
The cost category of "tunnel operation and maintenance" was $\$ 0.46 / \mathrm{ft}^{2}$ for lettuce and $\$ 0.9 \mathrm{l} / \mathrm{ft}^{2}$ for tomato. These results show that the total labor requirement per square foot for high tunnel lettuce and tomato production was 6 and 10 times greater than for open-field production, respectively. High tunnel production also had higher material cost and higher capital investment cost per square foot than open-field production.
ReLATIVE COST OF EACH FIELD ACTIVITY WITHIN A PRODUCTION SYsTEM. Total fixed costs and main categories of variable costs as a percentage of total production costs for each crop and production system are summarized in Fig. 1. Harvest and postharvest activities comprised a substantial portion of the total cost of production for both crops in both production systems; this category included labor-intensive harvest, packing,

Table 4. Estimated total production costs for lettuce and tomato, by field activity and by production system.

\begin{tabular}{|c|c|c|c|c|}
\hline \multirow[b]{2}{*}{ Field activity } & \multicolumn{4}{|c|}{ Total production costs ${ }^{\mathrm{z}}$} \\
\hline & $\begin{array}{c}\text { Open-field lettuce } \\
\left(\$ / \mathrm{ft}^{2}\right)\end{array}$ & $\begin{array}{l}\text { High tunnel } \\
\text { lettuce }\left(\$ / \mathrm{ft}^{2}\right)\end{array}$ & $\begin{array}{c}\text { Open-field } \\
\text { tomato }\left(\$ / \mathrm{ft}^{2}\right)\end{array}$ & $\begin{array}{l}\text { High tunnel } \\
\text { tomato }\left(\$ / \mathrm{ft}^{2}\right)\end{array}$ \\
\hline Field operations-Labor & 0.02 & 0.09 & 0.19 & 0.49 \\
\hline Field operations-Materials and custom ${ }^{\mathrm{y}}$ & 0.01 & 0.19 & 0.06 & 0.27 \\
\hline Harvest and postharvest-Labor & 0.12 & 0.34 & 0.11 & 1.48 \\
\hline Harvest and postharvest-Materials & 0.03 & 0.04 & 0.04 & 0.05 \\
\hline Other variable costs & 0.02 & 0.12 & 0.04 & 0.28 \\
\hline Total fixed costs & 0.04 & 0.29 & 0.03 & 0.30 \\
\hline
\end{tabular}

${ }^{2}$ Production costs were for square foot of total production area: $65,340 \mathrm{ft}^{2}$ [1.5 acres $\left.(0.61 \mathrm{ha})\right]$ for open-field lettuce; $54,450 \mathrm{ft}^{2}[1.25$ acres $(0.506 \mathrm{ha})]$ for open-field tomato; and $1920 \mathrm{ft}^{2}\left(178.4 \mathrm{~m}^{2}\right)$ for both high tunnel lettuce and high tunnel tomato; $\$ 1.00 / \mathrm{ft}^{2}=\$ 10.7639 / \mathrm{m}^{2}$.

${ }^{y}$ Custom field work included both the material applied on the field and labor involved. This category was present only in the open-field production of lettuce and tomato.

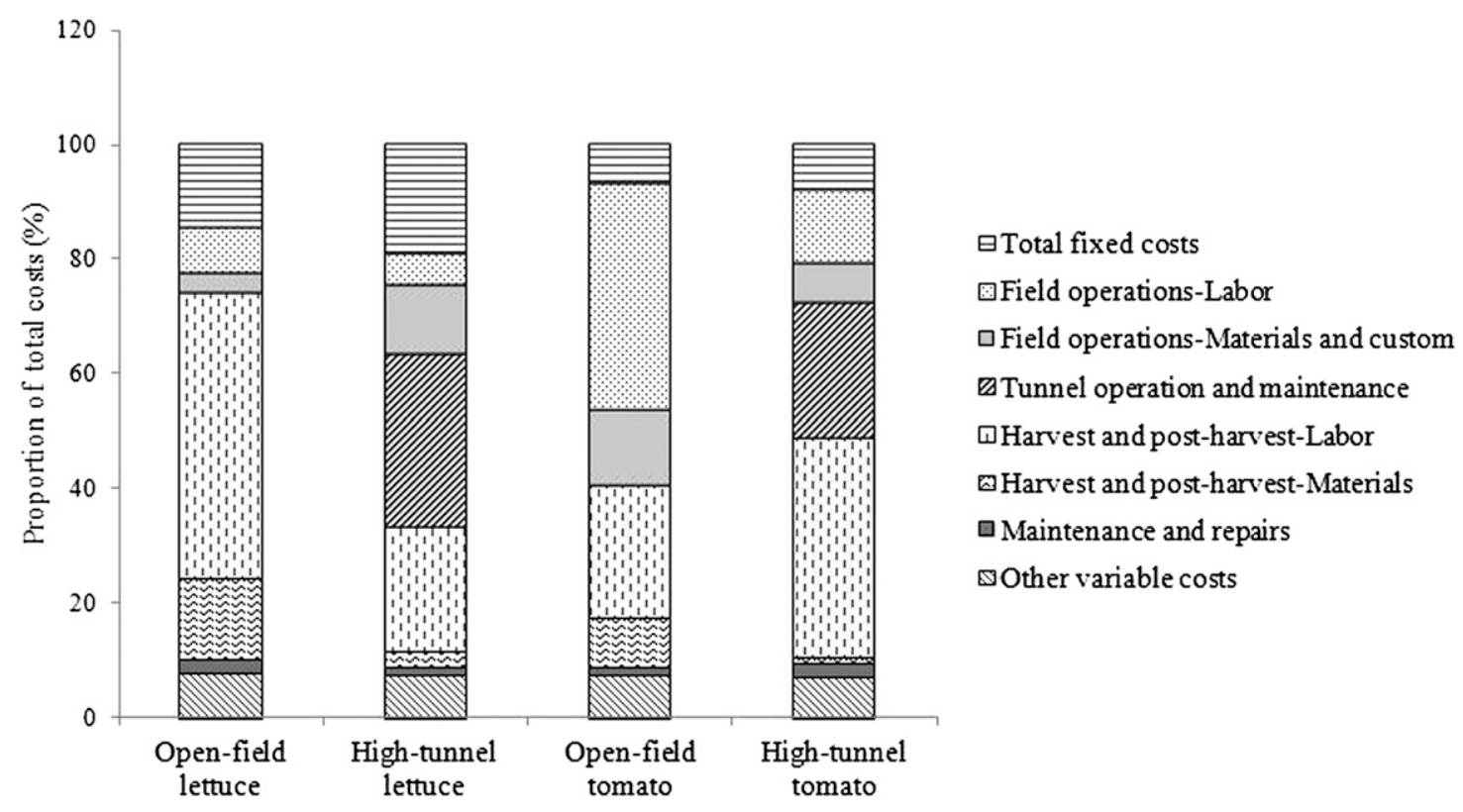

Fig. 1. Fixed costs and variable costs of high tunnel and open-field production based on grower input during focus group discussions for tomato and lettuce in western Washington in 2011 . Four focus groups, each with three to four experienced and knowledgeable commercial farmer participants, met from April through Nov. 2011, and participants reached consensus regarding costs and returns for each crop and cropping system. Field operations included soil preparation, planting, fertilizer and chemical application, and irrigation. Tunnel operation and maintenance included irrigation and fertigation management, temperature management, tunnel system maintenance (labor and some replacement parts), and tunnel setup and removal. Postharvest included packing (labor and materials) and direct marketing. Other variable costs included overhead cost and interest cost on operating capital (also organic certification fee in the case of open-field lettuce production and plastic mulch disposal cost in open-field tomato production). Total fixed costs included depreciation and interest on physical capital, interest and tax on land, farm insurance, and farm management. 
and direct marketing activities. For lettuce, harvest and postharvest activities varied by production system, and accounted for $\approx 64 \%$ of the total costs in the open-field system and $24 \%$ in the high tunnel system. For tomato, harvest and postharvest activities were similar for both production systems, and were $32 \%$ of the total costs for the open-field system and 39\% for the high tunnel system. The total cost of field operations was similar for lettuce in both production systems, and was $12 \%$ of the total costs for open-field production and $18 \%$ for the high tunnel. In contrast, for tomato, the field operations category differed for each production system, and was $52 \%$ of the total costs for open-field production and $20 \%$ for the high tunnel. The category of total fixed costs was similar for each crop regardless of production system, and ranged from $14 \%$ to $19 \%$ for lettuce and $7 \%$ to $8 \%$ for tomato. Other variable costs $(7 \%$ to $8 \%$ ) and costs for maintenance and repairs ( $1 \%$ to $2 \%$ ) were similar for both crops and both production systems. Tunnel operation and maintenance comprised the largest and second largest proportion, respectively, of the total production cost of high tunnel lettuce (30\%) and high tunnel tomato (23\%). Total labor cost was $58 \%$ of the total production costs for both field-grown and high tunnel lettuce. In contrast, total labor cost was $63 \%$ of the total production costs for field-grown tomato and $75 \%$ for high tunnel tomato.

LetTuCe PRofitability. High tunnel production provides growers an opportunity to produce crops early and beyond the main season, when there is less competition and prices are higher. The average price received for high tunnel grown lettuce was $\$ 2.50 /$ head early into the harvest season, and $\$ 1.75 /$ head late in the season (Table 3). During the main production season, the mean price received was $\$ 1.75 /$ head for lettuce grown in either the high tunnel or open field. Given the marketable yield and prices received during the crop season, it was profitable to produce lettuce in both the high tunnel and the open-field systems. However, the net return for producing lettuce in a high tunnel was $30 \%$ less per square foot than the net return for producing lettuce in the open field. Although there was a $150 \%$ yield advantage for high tunnel-grown lettuce as compared with the open field, the higher production costs for high tunnelgrown lettuce offset the yield advantage, which led to profit disadvantage.

Potential profit was sensitive to different combinations of lettuce yield and price within each production system. Assuming all other factors were constant, net returns were positive for open-field lettuce production for all yield and price combinations (Fig. 2). For high tunnel production, the average of the prices received during the early, middle, and late harvest seasons was $\$ 2 /$ head. To breakeven, the average price received during the entire crop season must be $\$ 2.01 /$ head when yield was $20 \%$ less than the base yield, $\$ 1.72 /$ head when yield was equal to the base yield, and $\$ 1.53 /$ head when yield was $20 \%$ greater than the base yield. When the yield and price were low $(20 \%$ below base yield and $\$ 1.75 /$ head, respectively), the profit for field-grown lettuce was $\$ 0.20 / \mathrm{ft}^{2}$, while the profit for high tunnel production was negative $\left(-\$ 0.19 / \mathrm{ft}^{2}\right)$. With the same low crop yield but a high price

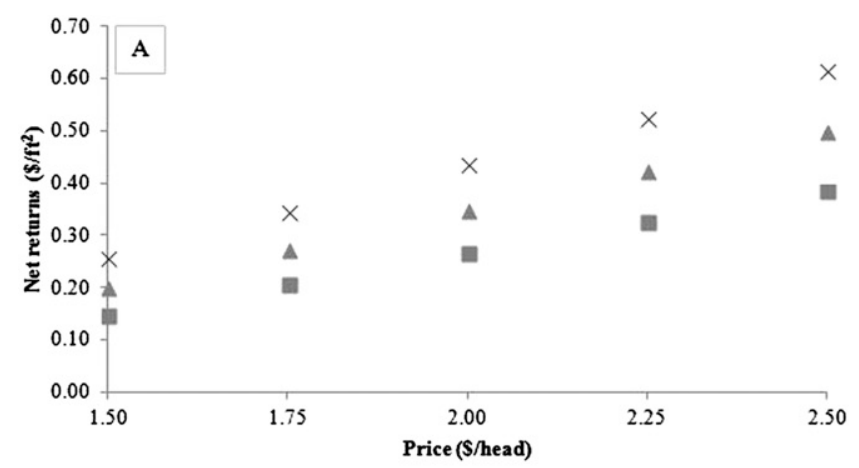

n-20\% Base yield $\Delta$ Base yield, field-grown lettuce $=0.36$ head $/ \mathrm{ft}^{2} \times+20 \%$ Base yield

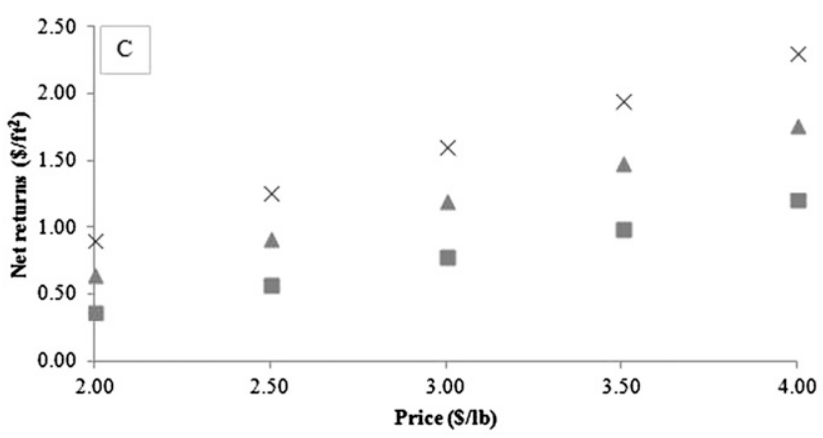

E-20\% Base yield $\Delta$ Base yield, field-grown tomato $=0.56 \mathrm{lb} / \mathrm{ft}^{2} \quad X+20 \%$ Base yield
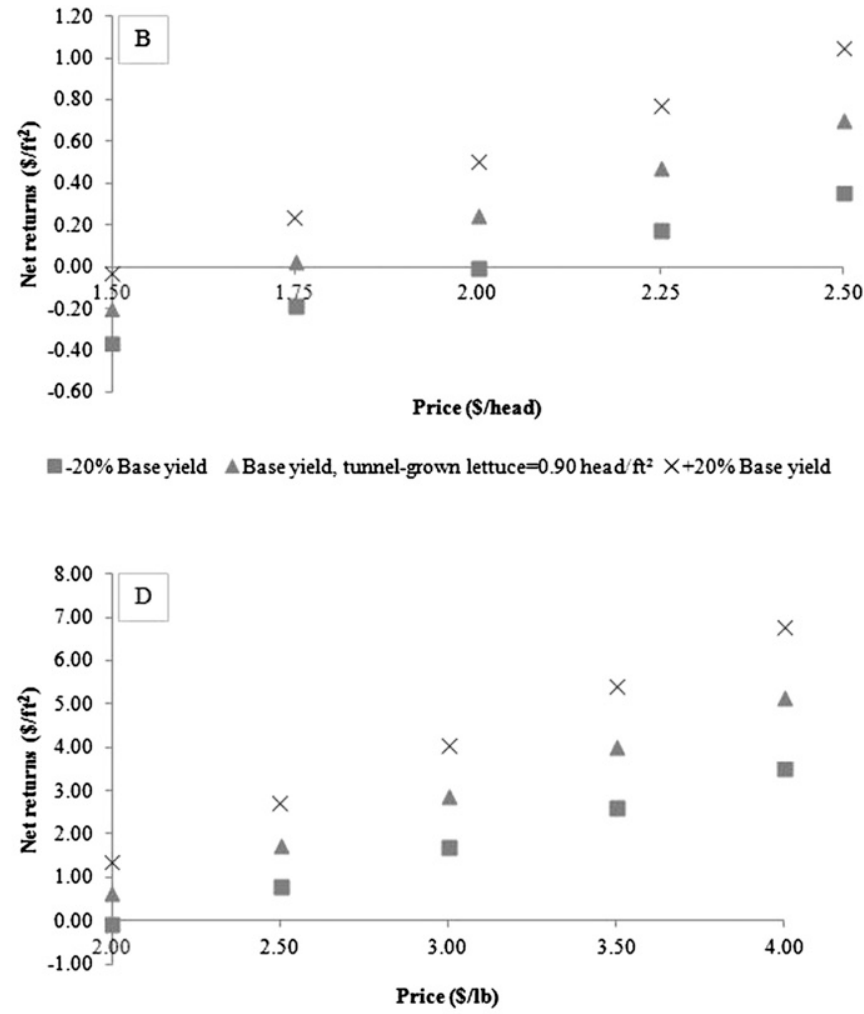

- $-20 \%$ Base yield $\Delta$ Base yield, tunnel-grown tomato $=2.25 \mathrm{lb} / \mathrm{ft}^{2} \quad X+20 \%$ Base yield

Fig. 2. Estimated net returns at different prices and yields in western Washington of (A) lettuce produced in open field, (B) lettuce produced in high tunnel, (C) tomato produced in open field, and (D) tomato produced in high tunnel; $\$ 1.00 / \mathrm{ft}^{2}=$ $\$ 10.7639 / \mathrm{m}^{2}, \$ 1.00 / \mathrm{lb}=\$ 2.2046 / \mathrm{kg}$. 
$(\$ 2.50 /$ head $)$, the profit for open-field production was $\$ 0.38 / \mathrm{ft}^{2}$ while the profit for high tunnel production was $7 \%$ less $\left(\$ 0.35 / \mathrm{ft}^{2}\right)$.

TOMATO PROFITABILITY. Tomato production in both high tunnel and open-field systems was profitable. During the main harvest season, the mean price received for field-grown or tunnel-grown tomato was $\$ 3 / \mathrm{lb}$, while mean prices during the early and late seasons were $\$ 4 / \mathrm{lb}$ and $\$ 3.50 / \mathrm{lb}$, respectively. Given the higher marketable yield and opportunity of selling tunnel-grown tomatoes beyond the main season at a premium price, the estimated net return was three times greater for high tunnel-grown tomato than for field-grown tomato.

The sensitivity of potential profit to different combinations of tomato yield and price within each production system is illustrated in Fig. 2. Net returns of open-field tomato production were positive for all yield and price combinations, assuming all other factors were constant. The average of the prices received for high tunnel grown tomato during the early, middle, and late seasons was $\$ 3.50 / \mathrm{lb}$. For high tunnel production to breakeven, the average price received during the entire crop season should be $\$ 2.05 / \mathrm{lb}$ when yield was $20 \%$ less than the base yield, $\$ 1.71 / 1 \mathrm{~b}$ when yield was equal to the base yield, and $\$ 1.49 / \mathrm{lb}$ when yield was $20 \%$ greater than the base yield. When the yield and price were low $(20 \%$ below base yield and $\$ 2 / \mathrm{lb}$, respectively), the profit for fieldgrown tomato was $\$ 0.37 / \mathrm{ft}^{2}$, while profit for high tunnel-grown tomato was $-\$ 0.08 / \mathrm{ft}^{2}$. Given the same low yield but a high price $(\$ 3.50 / \mathrm{lb})$, the profit for open-field production of tomato was $\$ 1.00 / \mathrm{ft}^{2}$, which was $62 \%$ less than the profit for high tunnel production $\left(\$ 2.62 / \mathrm{ft}^{2}\right)$.

\section{Discussion}

Lettuce and tomato are among the most popular direct market vegetable crops sold in western Washington. This study provides a comparison of production costs and returns for both crops and shows that it is economically feasible to produce both crops in either a high tunnel or openfield system. However, analyses of the different categories of production costs reveal that it is generally more expensive to grow lettuce and tomato in a high tunnel than in the open field as more labor and physical capital investment are needed to operate the relatively smaller growing area in a high tunnel. The increased labor in high tunnel operations has also been recognized by others, including Everhart et al. (2009), Giacomelli (2009), Hunter (2010), and Nennich et al. (2004). The total labor cost comprised more than $50 \%$ of the total production costs for lettuce and tomato in both production systems, and the cost share for labor was similar for lettuce in both systems while it was greater for tomato in high tunnel than in the open field. Additionally, high tunnel production has negative profitability when crop prices are low, i.e., below $\$ 2.01 /$ head and $\$ 2.05 / \mathrm{lb}$ for tunnelgrown lettuce and tomato, respectively, and whenever yield of either crop is $20 \%$ below the base yield. In contrast, open-field production is profitable for all price and yield combinations assumed in the study.

The feasibility of tomato production in a high tunnel has been extensively studied in different locations across the country (Table 5 ). In contrast, to date, there have been very few enterprise budgets calculated for high tunnel lettuce production. Cost estimates of high tunnel production

Table 5. Comparison of variable and fixed production costs from selected high tunnel lettuce and tomato enterprise budgets.

\begin{tabular}{|c|c|c|c|c|c|c|c|c|c|}
\hline \multirow[b]{2}{*}{ Study } & \multirow[b]{2}{*}{ Location } & \multirow[b]{2}{*}{$\begin{array}{l}\text { Area of high } \\
\text { tunnel }\left(\mathrm{ft}^{2}\right)^{\mathrm{z}}\end{array}$} & \multirow[b]{2}{*}{$\begin{array}{l}\text { Crop } \\
\text { yield }^{y}\end{array}$} & \multicolumn{3}{|c|}{ Variable costs ${ }^{\mathrm{x}}$} & \multicolumn{3}{|c|}{ Fixed costs ${ }^{\mathrm{x}}$} \\
\hline & & & & $\begin{array}{c}\text { Per } \\
\text { tunnel }\end{array}$ & Per $\mathrm{ft}^{2 \mathrm{w}}$ & $\begin{array}{l}\text { Per } \\
\text { unit }\end{array}$ & $\begin{array}{l}\text { Per } \\
\text { tunnel }\end{array}$ & $\operatorname{Per} \mathrm{ft}^{2 \mathrm{w}}$ & $\begin{array}{l}\text { Per } \\
\text { unit }\end{array}$ \\
\hline Chase $(2013)^{\mathrm{v}}$ & Iowa & 2,160 & 209 & $\$ 146$ & $\$ 0.81$ & $\$ 0.70$ & $\$ 81$ & $\$ 0.45$ & $\$ 0.39$ \\
\hline This study & Western Washington & 1,920 & 1,725 & $\$ 2,411$ & $\$ 1.26$ & $\$ 1.40$ & $\$ 554$ & $\$ 0.29$ & $\$ 0.32$ \\
\hline Bullen (2009) & North Carolina & 2,880 & 5,760 & $\$ 4,340$ & $\$ 1.51$ & $\$ 0.75$ & $\$ 1,282$ & $\$ 0.45$ & $\$ 0.22$ \\
\hline Chase $(2013)$ & Iowa & 2,160 & 5,888 & $\$ 1,619$ & $\$ 0.75$ & $\$ 0.27$ & $\$ 966$ & $\$ 0.45$ & $\$ 0.16$ \\
\hline Cornell University (2009) & New York & 2,000 & 5,780 & $\$ 1,905$ & $\$ 0.95$ & $\$ 0.33$ & $\$ 768$ & $\$ 0.38$ & $\$ 0.13$ \\
\hline Foord $(2004)^{\mathrm{u}}$ & Minnesota & 1,920 & 4,480 & $\$ 2,402$ & $\$ 1.25$ & $\$ 0.54$ & $\$ 1,189$ & $\$ 0.62$ & $\$ 0.27$ \\
\hline
\end{tabular}

${ }^{\mathrm{z}} 1 \mathrm{ft}^{2}=0.0929 \mathrm{~m}^{2}$.

'Total marketable crop yield per $1920-\mathrm{ft}^{2}$ tunnel; 1000 heads $/$ tunnel $=0.5208$ head $/ \mathrm{ft}^{2}=5.6062 \mathrm{heads} / \mathrm{m}^{2}, 1000 \mathrm{lb} / \mathrm{tunnel}=0.5208 \mathrm{lb} / \mathrm{ft}^{2}=2.5429 \mathrm{~kg} \cdot \mathrm{m}^{-2}$.

xThe production costs of this study for western Washington were as of 2011 prices. To make the figures from other studies comparable, their respective production costs have been adjusted with respect to the year 2011 using the Index for Prices Paid by Farmers for Production Items. The equation used was: cost $_{2011}=$ cost $_{\mathrm{t}} \mathrm{x}$ (Price Paid Index $2011 /$ Price Paid Index $x_{t}$ ) where $t$ refers to the year of the study's publication. The Price Paid Indexes for various years were: 132 (2004); 160 (2007); 182 (2009); 215 (2011); and 220 (2013). Price Paid Index data were obtained from USDA (2013); $\$ 1000 /$ tunnel $=\$ 0.5208 / \mathrm{ft}^{2}=\$ 5.6062 / \mathrm{m}^{2}, \$ 1.00 / \mathrm{lb}=\$ 2.2046 / \mathrm{kg}$.

"Variable and fixed production costs were expressed on per square foot of total production area: $65,340 \mathrm{ft}^{2}[1.5$ acres $(0.61$ ha $)]$ for open-field lettuce; $54,450 \mathrm{ft}^{2}[1.25$ acres $(0.506 \mathrm{ha})]$ for open-field tomato; and $1920 \mathrm{ft}^{2}$ for both high tunnel lettuce and high tunnel tomato. $\$ 1.00 / \mathrm{ft}^{2}=\$ 10.7639 / \mathrm{m}^{2}$.

"Lettuce was one of the multiple vegetable crops grown in the high tunnel. The production area for lettuce was about $8.38 \%$ of the total tunnel area. Based on this, the variable and fixed costs for lettuce was estimated at $8.38 \%$ of the total variable and fixed costs for the multiple crop production.

"Foord (2004) and Jett et al. (2004) examined high tunnel tomato profitability given different yields. The assumed medium yield of $14 \mathrm{lb}$ (6.4 kg) per plant for 320 plants in Foord $(2004)$ and $10 \mathrm{lb}(4.5 \mathrm{~kg})$ per plant for 170 plants $/ 1000 \mathrm{ft}^{2}\left(1.83\right.$ plants $\left./ \mathrm{m}^{2}\right)$ in Jett et al. (2004) were used in this table. 
from different studies vary due to factors such as: the high tunnel model; capital, labor, and natural resources; input prices; cultural practices; and management skills and practices. However, the values presented in Table 5 provide an informative range of the variable and fixed costs associated with tomato production in a high tunnel. The variable costs were $\$ 0.75-\$ 3.56 / \mathrm{ft}^{2}$ or $\$ 0.27-\$ 1.58 / \mathrm{lb}$; and the fixed costs were $\$ 0.30-\$ 0.66 / \mathrm{ft}^{2}$ or $\$ 0.13-$ $\$ 0.3 \mathrm{l} / \mathrm{lb}$. The estimated variable costs of this study were in the high end of the aforementioned range and about two standard deviations away from the mean. On the other hand, this study's fixed cost estimates were in the low end of the range and about one standard deviation away from the mean.

In the summer, price tends to be low for lettuce and tomato as compared with fall, winter, and spring production seasons. In addition, the longer daylength in the region in the summer combined with elevated temperatures in the high tunnel can reduce lettuce marketable yield because of bolting and tip burn (Wallace et al., 2012). These authors found that lettuce yield was similar in high tunnel and open-field production when grown from May through July in western Washington. In contrast, other studies report higher marketable yields of lettuce in a high tunnel as compared with open field (Belasco et al., 2012; Kelly, 2005; Rader and Karlsson, 2006). The variable results may be due to season of production as a high tunnel tends to reduce lettuce yield in the summer whereas yield may be increased during the remainder of the year. Thus high tunnel lettuce production is not likely to be profitable during the summer production period. While it costs two times more to grow tomato than lettuce in a high tunnel, the return from high tunnel-grown tomato is $\mathbf{1 5}$ times greater than from high tunnel-grown lettuce. This result is because of greater tomato yield and extended harvest period, both early and late in the season, due to elevated temperature in high tunnels.

A high tunnel offers many benefits to growers in addition to an increase in yield, such as protection from environmental stresses that affect crop quality and marketability, which include hail, frost, excessive rainfall, and high wind. Belasco et al. (2012) and Nennich et al. (2004) have highlighted the potential of a high tunnel system in minimizing production and financial risks, and suggested high tunnels as a risk management tool for specialty crop producers.

Tomato and lettuce both had higher marketable yields when grown in a high tunnel as compared with the open field. However, the higher crop yield achieved in a high tunnel was not sufficient to offset the increased costs of production for lettuce. Expected crop yield, therefore, should not be the primary driving force in choosing a high tunnel production system over the open-field system. Instead, crop yield in addition to market price of the crop as well as production costs must all be taken into account when examining the profitability for any crop and production system. Furthermore, some limitations to this study are worth noting. The study's data and outcomes regarding profitability were based on information provided by focus groups of tomato and lettuce growers in western Washington. Production costs and returns by individual growers may differ, thus the results of the study cannot be generalized to represent the population of farmers.

Other issues worth mentioning are the possible economies of scale that may be obtained, for example, due to the size of the tunnel, size of the farm operation, and grower's experience. A larger high tunnel will improve the economy of scale to cover fixed capital such as plastic and end walls. Also, operating more than one high tunnel will improve the economy of scale to cover fixed capital that is shared among tunnels, such as machinery (e.g., bed shaper, mulch layer) and irrigation system outlet. High tunnel growers may engage in "trial and error" in their cultural and management practices to investigate what would give them the best crop in terms of quantity and quality. They may make adjustments to the planting method or to temperature management, or they may make changes to their high tunnel structures. When the grower finds the most productive method of growing the crop in a high tunnel, and this method is repeated over time, this experience can lower the average costs of production. In-depth analyses about the sources of economies of scale in a high tunnel operation are worthy of exploration in a future study.

\section{Literature cited}

Antonelli, A., R.S. Blyther, S.J. Collman, R.E. Thornton, and R. Van Denburgh. 2004. Home gardens. Washington State Univ. Ext. Publ. EB0422.

Belasco, E., C. Miles, A. Wszelaki, and D. Inglis. 2012. The use of high tunnels and crop insurance to manage risk in specialty crop production. Proc. Women Agr. Educators Natl. Conf. 4:24. (abstr.).

Blomgren, T. and T. Frisch. 2007. High tunnels: Using low-cost technology to increase yields, improve quality, and extend the season. 20 Mar. 2013. <http:// www.uvm.edu/sustainableagriculture/ Documents/HighTunnels.pdf $>$.

Bullen, S.G. 2009. High tunnel budgets. 20 Mar. 2013. <http://www.cefs.ncsu.edu/ newsevents/eventarchives/2009/sosa2009/ hightunnel/hightunnelbudges02172009. pdf $>$.

Carey, E., L. Jett, W.J. Lamont, T. Nennich, M. Orzolek, and K.A. Williams. 2009. Horticultural crop production in high tunnels in the United States: A snapshot. HortTechnology 19(1):37-43.

Chase, C. 2013. Vegetable production budgets for a high tunnel. Iowa State Univ. Ext. Outreach Ag Decision Maker File Al-23. 20 Mar. 2013. <https:// www.extension.iastate.edu/agdm/crops/ $\mathrm{html} / \mathrm{al}-23 . \mathrm{html}>$.

Conner, D.S., K.B. Waldman, A.D. Montri, M.W. Hamm, and J.A. Biernbaum. 2010. Hoophouse contributions to economic viability: Nine Michigan case studies. HortTechnology 20(5):877-884.

Cornell University. 2009. Estimated production costs for tomatoes in an unheated high tunnel. 20 Mar. 2013. <http:// www.hort.cornell.edu/hightunnel/business/ budget.htm $>$.

Dufault, R.J., B. Ward, and R.L. Hassell. 2006. Planting date and romaine lettuce cultivar affect quality and productivity. HortScience 4l(3):640-645.

Everhart, E., R. Hansen, D. Lewis, L. Naeve, and H. Taber. 2009. Iowa high tunnel fruit and vegetable production manual. 20 Mar. 2013. <http://www. iowaproduce.org/pages/production/files/ high_tunnel/iowa_tunnel_guide.pdf $>$.

Foord, K. 2004. High tunnel marketing and economics. 20 Mar. 2013. <http:// www.extension.umn.edu/distribution/ horticulture/components/Ml218-12.pdf>.

Galinato, S.P. and C.A. Miles. 2012. 2011 Cost of producing fresh market field-grown head lettuce in western Washington. Washington State Univ. Ext. Publ. FS081E. 
Galinato, S.P., C.A. Miles, and S.S. Ponnaluru. 2012a. 2011 Cost estimates of producing high-tunnel tomatoes in western Washington. Washington State Univ. Ext. Publ. FS090E

Galinato, S.P., C.A. Miles, and S.S. Ponnaluru. 2012b. 2011 Cost estimates of producing head lettuce in high tunnels in western Washington. Washington State Univ. Ext. Publ. FS092E.

Galinato, S.P., C.A. Miles, and S.S. Ponnaluru. 2012c. 2011 Cost estimates of producing fresh market field-grown tomatoes in western Washington. Washington State Univ. Publ. FS080E.

Giacomelli, G.A. 2009. Engineering principles impacting high-tunnel environments. Hort Technology 19(1):30-33.

Hunter, B.L. 2010. Enhancing out-ofseason production of tomatoes and lettuce using high tunnels. Utah State Univ., Logan, UT, MS Thesis.

Hunter, B., D. Drost, and R. Ward. 2011. High tunnel early tomato budget. 20 Mar. 2013. <https://extension.usu.edu/ agribusiness/files/uploads/specialty/pdf/ $2011 \% 20$ Early $\% 20$ Tomato $\% 20$ High $\%$ 20 Tunnel\%20.pdf $>$.

Jeavons, J. 2006. How to grow more vegetables. 7th ed. Ten Speed Press, New York.

Jett, L. 2011. Production and economics of high tunnel vegetables and strawberries. 20 Mar. 2013. <http://anr.ext.wvu.edu/ commercial_horticulture/high_tunnels / high_tunnel_vegetables_and_strawberries $>$.

Jett, L.W., D. Coltrain, J. Chism, J. Quinn, and A. Read. 2004. High tunnel tomato production. Univ. Missouri Ext. M170. 20 Mar. 2013. <http://extension. missouri.edu/p/M170>.

Kelly, K. 2005. Shade-covered high tunnels for summer production of lettuce and leafy greens. Organic Farming Res. Foundation, Santa Cruz, CA

Lamont, Jr., W.J., 2009. Overview of the use of high tunnels worldwide. HortTechnology 19(1):25-29.

Maynard, D.N. and G.J. Hochmuth. 1997. Knott's handbook for vegetable growers. 4th ed. Wiley, Hoboken, NJ.

Miles, C., C. Beus, A. Corbin, R. Wallace, A. Wszelaki, H. Saez, T. Walters, K. Leonas, M. Brodhagen, D. Hayes, and D. Inglis. 2009. Research and extension priorities to ensure adaptation of high tunnels and biodegradable plastic mulch in the United States. Proc. Natl. Agr. Plastics Congr. 35:102-107.

Miles, C., R. Wallace, A. Wszelaki, J. Martin, J. Cowan, T. Walters, and D. Inglis. 2012. Deterioration of potentially biodegradable alternatives to black plastic mulch in three tomato production regions. HortScience 47(9):1270-1277.

Mishagi, I.J., N.F. Oebker, and R.B. Hine. 1992. Prevention of tipburn in iceberg lettuce during postharvest storage. Plant Dis. 76:1169-1171.

Nennich, Sr., T.T., D. Wildung, and P. Johnson. 2004. Minnesota high tunnel production manual for commercial growers. 20 Mar. 2013. <http://www.extension. umn.edu/distribution/horticulture/ M1218.html>.

Rader, H.B. and M.G. Karlsson. 2006 Northern field production of leaf and romaine lettuce using a high tunnel. HortTechnology 16(4):649-654.

Reeve, J. and D. Drost. 2012. Yields and soil quality under transitional organic high tunnel tomatoes. HortScience 47(1): 38-44.

Rodriguez, H.G., J. Popp, M. Thomsen, H. Friedrich, and C.R. Rom. 2012. Economic analysis of investing in open-field or high tunnel primocane-fruiting blackberry production in northwestern Arkansas. HortTechnology 22(2):245-251.

Upson, S. 2009. Economic feasibility of hoop house tomato production. 20 Mar. 2013. <http://www.noble.org/ag/ Horticulture/HoopTomato/Index.htm>.

U.S. Census Bureau. 2012. The 2012 statistical abstract: The national data book. Table 862 - Commercial vegetable and other specified crops - Area, production, and value, and leading producing states. 20 Mar. 2013. <http://www.census. gov/compendia/statab/cats/agriculture/ crops.html $>$.

U.S. Department of Agriculture. 2010. U.S. tomato statistics, Table067. 20 Mar. 2013. <http://usda.mannlib.cornell. edu/MannUsda/viewDocumentInfo. do?documentID =1210>

U.S. Department of Agriculture. 2011. U.S. lettuce statistics, Table 32. 20 Mar. 2013. <http://usda01.library.cornell. edu/usda/ers/Lettuce/Table32.xls>.

U.S. Department of Agriculture. 2012. Food availability (per capita) data system, vegetables (fresh). 20 Mar. 2013. <http:// www.ers.usda.gov/data-products/foodavailability-(per-capita)-data-system.aspx $>$.

U.S. Department of Agriculture. 2013. Quick Stats 2.0: Economics - Index for price paid 1990-1992. 20 Mar. 2013. <http://www.nass.usda.gov/Quick_Stats/>.

Veseys. n.d. Vegetable planting chart. 20 Mar. 2013. <http://www.veseys.com/ us/en/learn/reference/plantingchart $>$.

Waldman, K.B., D.S. Conner, J.A. Biernbaum, M.W. Hamm, and A.D. Montri. 2012. Determinants of hoophouse profitability: A case study of 12 novice Michigan farmers. HortTechnology 22(2): 215-223.

Wallace, R.W., A.L. Wszelaki, C.A. Miles, J.S. Cowan, J. Martin, J. Roozen, B. Gundersen, and D.A. Inglis. 2012. Lettuce yield and quality when grown in high tunnel and open-field production systems under three diverse climates. HortTechnology 22(5):659-668.

Washington State Commission on Pesticide Registration. 2010. Compendium of Washington agriculture: Tomato. 20 Mar. 2013. <http://69.93.14.225/ wscpr/LibraryDocs/Tomato2010.pdf>.

Waterer, D. 2003. Yields and economics of high tunnels for production of warmseason vegetable crops. HortTechnology 13(2):339-343

Wells, O.S. and J.B. Loy. 1993. Rowcovers and high tunnels enhance crop production in the northeastern United States. HortTechnology 3(1):92-95.

Wien, H.C. 1997. Lettuce, p. 479-509. In: H.C. Wien (ed.). The physiology of vegetable crops. $\mathrm{CAB}$ International, New York, NY.

Wien, H.C., M.I. Gomez, and B. Rickard. 2010. The economics of high tunnels. Amer. Veg. Grower 58(10):18-20.

Wiswall, R. 2009. The organic farmer's business handbook: A complete guide to managing finances, crops and staff-and making profit. Chelsea Green Publishing, White River Junction, VT.

Zhao, X. and E.E. Carey. 2009. Summer production of lettuce, and microclimate in high tunnel and open-field plots in Kansas. HortTechnology 19(1):113119. 